\title{
Sterelactones: New Isolactarane Type Sesquiterpenoids with Antifungal Activity from Stereum sp. IBWF 01060
}

\author{
Till Opatz, Heinz Kolshorn, Heidrun Anke
}

Received: June 24, 2008 / Accepted: August 29, 2008

(C) Japan Antibiotics Research Association

\begin{abstract}
Four members of a new family of tetracyclic sesquiterenoids possessing the isolactarane skeleton have been isolated from mycelial cultures of Stereum sp. IBWF 01060. Their structure elucidation and their antifungal activity against several plant pathogens as well as other microorganisms are reported.
\end{abstract}

Keywords sesquiterpenoids, isolactaranes, fungicide, structure elucidation, NMR spectroscopy

\section{Introduction}

Extracts from mycelial cultures of the basidiomycete Stereum sp. IBWF 01060 exhibit strong activity against several phytopathogenic fungi such as Magnaporthe grisea (rice blast fungus), Fusarium graminearum (wheat head blight fungus), and Phytophthora infestans (potato late blight fungus). The search for the active principle resulted in the isolation of the sterelactones $A \sim D$, the structure elucidation and the biological evaluation of which are reported.

The basidiomycete was grown in YMG-medium at ambient temperature until the glucose was consumed (11 days). The mycelia were removed by filtration and the culture filtrate (15 liters) was extracted with EtOAc $(2 \times 6.0$ liters). Removal of the solvent in vacuo, fractionation and purification by silica gel column chromatography followed by separation by preparative reversed phase HPLC furnished four pure single compounds of different polarity

Till Opatz (Corresponding author): Institute of Organic Chemistry, University of Hamburg, Martin-Luther-King-Platz 6, 20146 Hamburg, Germany, E-mail: opatz@chemie.unihamburg.de but highly similar spectroscopic properties. Sterelactones A (1, 6.4 mg), B (2, $47 \mathrm{mg}), \mathrm{C}(3,38 \mathrm{mg})$, and D (4, 15.6 mg) were obtained as yellowish or slightly amber oils. APCIMS revealed mass differences of 28 units, in each case attributable to two additional methylene groups as judged by NMR and ESI-HRMS. The sterelactones exhibited almost identical UV-spectra with a pronounced absorption maximum at $304 \mathrm{~nm}(\log \varepsilon=3.9 \sim 4.0)$ in $\mathrm{MeOH}$. In combination with the consistent IR absorption at $1667 \mathrm{~cm}^{-1}$ and a singlet signal in the ${ }^{1} \mathrm{H}-\mathrm{NMR}$ spectra at $9.82 \mathrm{ppm}$, this suggests the presence of a 2,4-dienal moiety, which is further supported by the presence of four olefinic carbon atoms with alternating ${ }^{13} \mathrm{C}$ chemical shifts: $\alpha(\mathrm{C}-3$,
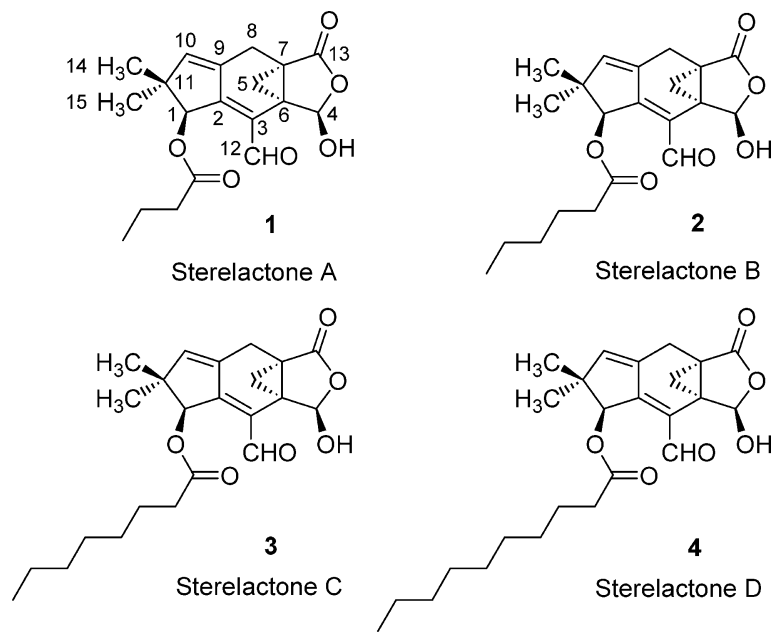

Fig. 1 Structures of the Sterelactones including the atomic numbering scheme.

Heinz Kolshorn: Institute of Organic Chemistry, University of Mainz, Duesbergweg 10-14, 55128 Mainz, Germany

Heidrun Anke: Institute of Biotechnology and Drug Research, Erwin-Schrödinger-Str. 56, 67663 Kaiserslautern, Germany 
Table $1{ }^{1} \mathrm{H}$ Chemical shifts (ppm, $\mathrm{CDCl}_{3}$ ) of the sterelactones

\begin{tabular}{|c|c|c|c|c|}
\hline Atom No. & Sterelactone A & Sterelactone B & Sterelactone C & Sterelactone D \\
\hline $1-\mathrm{H}$ & $5.93(\mathrm{~s})$ & $5.93(\mathrm{~s})$ & $5.93(\mathrm{~s})$ & $5.93(\mathrm{~s})$ \\
\hline $4-\mathrm{H}$ & $6.08 \sim 6.20(\mathrm{br} \mathrm{s})^{\mathrm{a}}$ & $6.10 \sim 6.24(\mathrm{br} \mathrm{s})^{\mathrm{a}}$ & $6.10 \sim 6.23(\mathrm{br} \mathrm{s})^{\mathrm{a}}$ & $6.11 \sim 6.26(\mathrm{brs})^{\mathrm{a}}$ \\
\hline $5-\mathrm{H}_{2}$ & $1.57^{b} / 0.98(\mathrm{brd}, \approx 5 \mathrm{~Hz})$ & $1.55 / 0.99(\mathrm{brd}, 4.8 \mathrm{~Hz})$ & $1.55 / 0.99(\mathrm{brd}, 4.8 \mathrm{~Hz})$ & $1.55 / 0.99(\mathrm{brd}, 4.8 \mathrm{~Hz})$ \\
\hline $8-\mathrm{H}_{2}$ & $3.11 / 2.98(\mathrm{brd}, 18.0 \mathrm{~Hz})$ & $3.11 / 2.98(\mathrm{br} \mathrm{d}, 18.0 \mathrm{~Hz})$ & 3.11/2.98 (br d, $18.0 \mathrm{~Hz})$ & 3.11/2.97 (br d, $18.0 \mathrm{~Hz})$ \\
\hline $10-\mathrm{H}$ & $6.08 \sim 6.20(\mathrm{br} \mathrm{s})^{\mathrm{a}}$ & $6.10 \sim 6.24(\mathrm{br} \mathrm{s})^{\mathrm{a}}$ & $6.10 \sim 6.23(\mathrm{br} \mathrm{s})^{\mathrm{a}}$ & $6.11 \sim 6.26(\mathrm{br} \mathrm{s})^{\mathrm{a}}$ \\
\hline $12-\mathrm{H}$ & $9.83(\mathrm{~s})$ & $9.82(\mathrm{~s})$ & $9.82(\mathrm{~s})$ & $9.82(\mathrm{~s})$ \\
\hline $14-\mathrm{H}_{3}$ & $1.05(\mathrm{~s})$ & $1.04(\mathrm{~s})$ & $1.04(\mathrm{~s})$ & $1.04(\mathrm{~s})$ \\
\hline $15-\mathrm{H}_{3}$ & $1.21(\mathrm{~s})$ & $1.21(\mathrm{~s})$ & $1.21(\mathrm{~s})$ & $1.21(\mathrm{~s})$ \\
\hline Alkyl chain & $\begin{array}{l}2.30 \sim 2.42\left(\mathrm{~m}, \alpha-\mathrm{CH}_{2}\right) \\
\left.1.68 \text { (sextet, } 7.4 \mathrm{~Hz}, \beta-\mathrm{CH}_{2}\right), \\
0.96\left(\mathrm{t}, 7.4 \mathrm{~Hz}, \mathrm{CH}_{3}\right)\end{array}$ & $\begin{array}{l}2.31 \sim 2.43\left(\mathrm{~m}, \alpha-\mathrm{CH}_{2}\right), \\
1.64\left(\mathrm{mc}, \beta-\mathrm{CH}_{2}\right) \\
1.25 \sim 1.36\left(\mathrm{~m}, 2 \times \mathrm{CH}_{2}\right), \\
0.89\left(\mathrm{t}, 6.9 \mathrm{~Hz}, \mathrm{CH}_{3}\right)\end{array}$ & $\begin{array}{l}2.31 \sim 2.43\left(\mathrm{~m}, \alpha-\mathrm{CH}_{2}\right), \\
1.63\left(\mathrm{mc}, \beta-\mathrm{CH}_{2}\right) \\
1.23 \sim 1.34\left(\mathrm{~m}, 4 \times \mathrm{CH}_{2}\right) \\
0.87\left(\mathrm{t}, 6.9 \mathrm{~Hz}, \mathrm{CH}_{3}\right)\end{array}$ & $\begin{array}{l}2.31 \sim 2.43\left(\mathrm{~m}, \alpha-\mathrm{CH}_{2}\right), \\
1.63\left(\mathrm{mc}, \beta-\mathrm{CH}_{2}\right), \\
1.22 \sim 1.34\left(\mathrm{~m}, 6 \times \mathrm{CH}_{2}\right), \\
0.88\left(\mathrm{t}, 6.8 \mathrm{~Hz}, \mathrm{CH}_{3}\right)\end{array}$ \\
\hline
\end{tabular}

a Overlap.

${ }^{\mathrm{b}}$ Broad signal, no coupling observable.

Table $2{ }^{13} \mathrm{C}$ Chemical shifts (ppm, $\mathrm{CDCl}_{3}$ ) of the sterelactones

\begin{tabular}{|c|c|c|c|c|}
\hline Atom No. & Sterelactone A & Sterelactone B & Sterelactone C & Sterelactone D \\
\hline C-1 & 76.1 & 76.1 & 76.1 & 76.1 \\
\hline C-2 & $157.6^{\mathrm{a}}$ & $157.6^{a}$ & $157.6^{a}$ & $157.6^{a}$ \\
\hline C-3 & 128.1 & 128.1 & 128.1 & 128.1 \\
\hline C-4 & 97.6 & 97.5 & 97.4 & 97.4 \\
\hline$C-5$ & $27.8^{\mathrm{a}}$ & $27.9^{a}$ & $27.9^{a}$ & $27.8^{\mathrm{a}}$ \\
\hline C-6 & 32.7 & 32.7 & 32.7 & 32.7 \\
\hline $\mathrm{C}-7$ & $26.5^{\mathrm{a}}$ & $26.6^{a}$ & $26.6^{\mathrm{a}}$ & $26.6^{a}$ \\
\hline C-8 & 20.0 & 20.0 & 20.0 & 20.0 \\
\hline C-9 & 133.4 & 133.3 & 133.3 & 133.3 \\
\hline$C-10$ & 152.1 & 152.1 & 152.1 & 152.1 \\
\hline C-11 & 49.2 & 49.2 & 49.2 & 49.2 \\
\hline$C-12$ & 189.5 & 189.4 & 189.4 & 189.4 \\
\hline C-13 & $175.0^{\mathrm{a}}$ & $175.1^{\mathrm{a}}$ & $175.0^{\mathrm{a}}$ & $175.1^{\mathrm{a}}$ \\
\hline$C-14$ & 21.3 & 21.3 & 21.3 & 21.4 \\
\hline C-15 & 27.6 & 27.6 & 27.6 & 27.6 \\
\hline Ester-CO & 172.9 & 173.1 & 173.1 & 173.1 \\
\hline Alkyl chain & $\begin{array}{l}36.0(\alpha), 18.4(\beta), \\
13.7\left(\mathrm{CH}_{3}\right)\end{array}$ & $\begin{array}{l}34.1(\alpha), 24.5,22.2,31.2 \\
13.9\left(\mathrm{CH}_{3}\right)\end{array}$ & $\begin{array}{l}34.2(\alpha), 31.6,29.1,28.8 \\
24.9,22.6,14.0\left(\mathrm{CH}_{3}\right)\end{array}$ & $\begin{array}{l}34.2(\alpha), 31.8,29.4 \\
29.2(2 \times), 29.1,24.9, \\
22.6,14.1\left(\mathrm{CH}_{3}\right)\end{array}$ \\
\hline
\end{tabular}

a Very broad resonance.

$128.1 \mathrm{ppm}), \beta(\mathrm{C}-2,157.6 \mathrm{ppm}), \gamma(\mathrm{C}-9,133.4 \mathrm{ppm})$, and $\delta$ $(\mathrm{C}-10,152.1 \mathrm{ppm})$, and an upfield-shifted aldehyde carbon $(\mathrm{C}-12,189.4 \mathrm{ppm})$. For sterelactone $\mathrm{B}\left(\mathrm{C}_{21} \mathrm{H}_{26} \mathrm{O}_{6}\right)$, the structure of the tetracyclic core could be established to be identical to that of other isolactaranes by two-dimensional NMR spectroscopy (COSY, HSQC, HMBC, NOESY)
$[1,2]$. The $\beta, \gamma$-bond of the dienal joins a five- and a six-membered ring to a 2,4,5,6-tetrahydro- $1 H$-indene substructure. Its five-membered ring carries a geminal dimethyl group and a secondary hydroxyl group, which is esterified with $n$-hexanoic acid. Sterelactone $\mathrm{A}$ is a $n$ butyrate while the less polar sterelactones $\mathrm{C}$ and $\mathrm{D}$ are 
esters of $n$-octanoic and $n$-decanoic acid, respectively (Fig. $1)$.

In the NMR spectra, many carbon and proton resonances are strongly broadened, which particularly holds true for the western part of the molecule. Presumably, the dynamics of the 5-hydroxy-dihydrofuran-2-one moiety is responsible for this effect that has already been reported by Erkel et al. for the closely related hyphodontal [3]. As a consequence of this line broadening in both dimensions, several expected HMBC correlations could not be detected. Nevertheless, the oxidation state of carbons 4 and 13, i.e. the position of the lactone and the lactol center, could be established by a significant HMBC correlation between the slightly deshielded $8-\mathrm{H}_{2}$ methylene proton and $\mathrm{C}-13$ to be identical to the arrangement in hyphodontal. The relative configuration of the sterelactones was deduced from weak NOE contacts between 4-H and 5- $\mathrm{H}_{\mathrm{a}}$ as well as between 1$\mathrm{H}$ and $5-\mathrm{H}_{\mathrm{b}}$ (Fig. 2). Thus, the cyclopropane ring is located on the same side as both the carbinol proton at $\mathrm{C}-1$ and the lactol proton. The absolute configuration of the tetracyclic core was tentatively assigned in analogy to the isolactaranes merulidial $[4,5]$ and hyphodontal.

The sterelactones showed antibacterial, antifungal and cytotoxic activities. The obtained amounts of sterelactone A were not sufficient to allow broad testing - the activities measured were slightly lower than those of the other sterelactones as shown in Table 3 . The cytotoxic activity of all compounds was moderate with compound $\mathbf{1}$ showing the lowest activity. The antifungal activities were more pronounced than the antibacterial activities. The yeast Nematospora coryli turned out to be the most sensitive organism in the agar diffusion assay. The length of the side chain seems to play an important role, the optimal length being eight carbon atoms, i.e. sterelactone $\mathrm{C}$ was the most active compound. In addition to the activities given in Table 3 , sterelactone D exhibited weak nematicidal activity
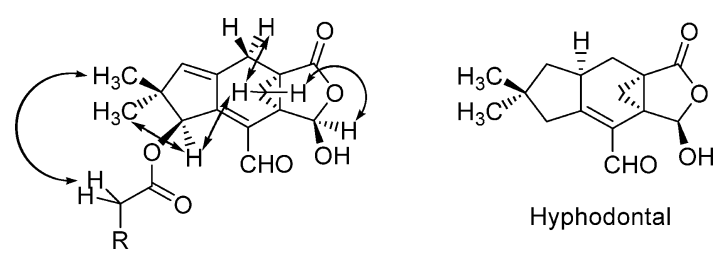

Hyphodontal

Fig. 2 Important NOE contacts in the sterelactone skeleton and the structure of hyphodontal.

Table 3 Antimicrobial activities of sterelactones A D as measured in a germination assay using fungal conidia, in the disk diffusion assay with $50 \mu \mathrm{g}$ per filter disk (6 mm diameter) and cytotoxic activity in a cell proliferation assay

\begin{tabular}{|c|c|c|c|c|}
\hline Biological activity & Sterelactone A & Sterelactone B & Sterelactone C & Sterelactone D \\
\hline \multicolumn{5}{|l|}{ Conidia germination $\mathrm{IC}_{100}(\mu \mathrm{g} / \mathrm{ml})$} \\
\hline Magnaporthe grisea & 5.0 & 5.0 & 1.0 & 1.0 \\
\hline Fusarium graminearum & 2.5 & 1.0 & 1.0 & 1.0 \\
\hline Botrytis cinerea & $\mathrm{nt}^{*}$ & $>50$ & $>50$ & $>50$ \\
\hline Phytophthora infestans & 5.0 & 2.5 & 1.0 & 1.0 \\
\hline Penicillium notatum & $\mathrm{nt}$ & 50 & 10 & 10 \\
\hline Paecilomyces variotii & $\mathrm{nt}$ & $>50$ & 20 & 50 \\
\hline Mucor miehei & nt & 50 & 20 & 50 \\
\hline \multicolumn{5}{|c|}{ Agar diffusion assay Inhibition zone with $50 \mu \mathrm{g} / \mathrm{disk}$ (mm) } \\
\hline Bacillus brevis & nt & 14 & 17 & 16 \\
\hline Bacillus subtilis & nt & 12 & 17 & 15 \\
\hline Micrococcus luteus & nt & - & 7 & 7 \\
\hline Staphylococcus aureus & 0 & 0 & 7 & 7 \\
\hline E. coli K12 & nt & $>50$ & $>50$ & $>50$ \\
\hline Enterobacter dissolvens & $\mathrm{nt}$ & $>50$ & $>50$ & $>50$ \\
\hline Proteus vulgaris & 13 & 16 & 18 & 15 \\
\hline Nematospora coryli & 10 & 28 & 34 & 14 \\
\hline Candida albicans & 0 & 11 & 24 & 17 \\
\hline \multicolumn{5}{|l|}{ Cytotoxic activity $\mathrm{IC}_{50}(\mu \mathrm{g} / \mathrm{ml})$} \\
\hline HeLa S3 cells & 20 & 10 & 10 & 10 \\
\hline Hep G2 cells & 20 & 10 & 10 & 10 \\
\hline
\end{tabular}

${ }^{*} \mathrm{nt}=$ not tested. 
towards Caenorhabditis elegans, at $100 \mu \mathrm{g} / \mathrm{ml}$ more than $50 \%$ of the nematodes were dead. Phytotoxic activity towards Setarica italica and Lepidium sativum were not observed up to $300 \mu \mathrm{g} / \mathrm{ml}$. The pronounced antimicrobial activity exhibited by the sterelactones presumably originates from their masked dialdehyde structure and the unsaturated aldehyde moiety, which makes them potential crosslinking agents by means of direct and/or vinylogous addition.

\section{Experimental}

\section{Producing Organism}

Strain IBWF 01060 was obtained from the spore print of a fruiting body of a Stereum species growing on a dead woody twig of Spartium junceum in France. The strain is maintained on YMG agar (4.0 g yeast extract (Hartge Ingriedients, Hamburg), $10 \mathrm{~g}$ malt extract (Difco Laboratories, Detroit), $4.0 \mathrm{~g}$ glucose and $15 \mathrm{~g}$ agar (Difco Agar, Granulated, Becton Dickinson and Co., Sparks, USA) in 1.0 liter distilled water). It is deposited in the strain collection of the IBWF (Institute of Biotechnology and Drug Research, Kaiserslautern).

\section{Fermentation and Isolation}

The producing organism was cultivated in YMG medium containing per liter $\mathrm{H}_{2} \mathrm{O}$ : yeast extract $4.0 \mathrm{~g}$, malt extract $10 \mathrm{~g}$, glucose $4.0 \mathrm{~g}$ in 1.0 liter tap water. Fermentations were carried out in a 20-liter fermentor (Biostat A-20, Braun, Melsungen) at $22^{\circ} \mathrm{C}$, with aeration 3.0 liters/minute and agitation $120 \mathrm{rpm}$. A well-grown shake culture $(250 \mathrm{ml}$, 9 days old) in the same medium was used as inoculum. After 11 days when the glucose was used up (measured with the Diabur-test $5000^{\circledR}$, Roche Diagnostics, Mannheim), the culture fluid was separated from the mycelia by filtration. The culture fluid (15 liters) was extracted with EtOAc $(2 \times 6.0$ liters $)$ and the organic phase concentrated in vacuo. The crude extract ( $1.8 \mathrm{~g})$ was applied onto a silica gel column (Merck 60, 0.063 $0.2 \mathrm{~mm}$, size $4.5 \times 24 \mathrm{~cm})$. Elution with cyclohexane/EtOAc $4: 1 \sim 7: 3$ resulted in an intermediate product $(482 \mathrm{mg}$ ) which was further purified by preparative HPLC (Merck Lichrosorb $^{\circledR}$ RP18, $5.0 \mu \mathrm{m}$, column $25 \times 250 \mathrm{~mm}$, flow $20 \mathrm{ml} /$ minute; gradient $\mathrm{H}_{2} \mathrm{O} / \mathrm{MeCN} 20$ to $100 \% \mathrm{MeCN}$ in 20 minutes) yielded sterelactones $\mathrm{B}(47 \mathrm{mg}$, eluted with $87 \% \mathrm{MeCN}$ ), C (38 mg, eluted with 97\% MeCN) and D ( $15.6 \mathrm{mg}$, eluted with $100 \% \mathrm{MeCN})$. Along with these pure compounds, an intermediate product $(85 \mathrm{mg}$, eluted with $78 \% \mathrm{MeCN}$ ) was obtained, from which sterelactone A $(6.4 \mathrm{mg})$ could be isolated after a second preparative HPLC run (Merck Lichrosorb ${ }^{\circledR} \mathrm{RP} 18,5.0 \mu \mathrm{m}$, column $25 \times 250$ $\mathrm{mm}$, flow $20 \mathrm{ml} / \mathrm{minute}$; isocratic $\mathrm{MeCN} / \mathrm{H}_{2} \mathrm{O} 50: 50$ ) The isolation of the antifungal compounds was guided by the antifungal activity in the agar diffusion assay with $N$. coryli as test organism.

\section{Biological Assays}

Hela S3 (ATCC CCL 2.2 human cervix carcinoma) and Hep G2 (DSMZ ACC 180, human liver carcinoma) cells were grown in DMEM-medium with $65 \mu \mathrm{g} / \mathrm{ml}$ of penicillin $\mathrm{G}$ and $100 \mu \mathrm{g} / \mathrm{ml}$ of streptomycin sulfate. The cells $\left(10^{5}\right.$ cells $\left./ \mathrm{ml}\right)$ were incubated in microtiter plates with the compounds at $37^{\circ} \mathrm{C}$ in a humidified atmosphere containing $5.0 \% \mathrm{CO}_{2}$. Viable cells were counted under the microscope after 24 and 48 hours [6]. The antifungal activity was measured in a spore germination assay with conidia of phytopathogenic as well as saprophytic fungi. The test was carried out in 96 well microtiterplates holding $200 \mu \mathrm{l}$ per well. Condidia $\left(5 \times 10^{4}\right.$ conidia $\left./ \mathrm{ml}\right)$ were suspended in distilled water (M. grisea), or in water with $0.4 \%$ glucose (F. graminearum) or YMG medium for the other strains. The compounds were added dissolved in $\mathrm{MeOH}$. The maximum concentration of $\mathrm{MeOH}$ in the assay was $1.0 \%$. The plates were incubated at $27^{\circ} \mathrm{C}$. After 18 hours the test was evaluated under the microscope. Germination of the conidia was compared to the controls containing only $\mathrm{MeOH}$. In each well 100 condidia were counted. The $\mathrm{IC}_{100}$ value are given as the concentrations at which the germination of the conidia was completely inhibited. The tests were carried out in triplicates.

The antimicrobial spectrum of the compounds was evaluated using the conventional agar diffusion assay. Yeasts were assayed in YMG agar and bacteria in nutrient broth (Difco Laboratories, Detroit). Nematicidal activity towards Meloidogyne incognita and C. elegans was determined as described earlier [7].

\section{Spectroscopy}

${ }^{1} \mathrm{H}-\mathrm{NMR}$ (400 MHz) and ${ }^{13} \mathrm{C}-\mathrm{NMR}(100.6 \mathrm{MHz}$ ) were recorded at $25^{\circ} \mathrm{C}$ with a Bruker Avance-II spectrometer equipped with an inverse multinuclear $5 \mathrm{~mm}$ probehead and a z-gradient coil. The spectra were measured in $\mathrm{CDCl}_{3}$ and the chemical shifts were referenced to the residual solvent signal $\left(\mathrm{CDCl}_{3}: \delta_{\mathrm{H}}=7.26, \delta_{C}=77.0\right)$. Standard pulse sequences for gs-COSY, gs-HSQC, gs-HMBC, and gsNOESY experiments were used. The refocussing delays for the inverse heterocorrelation experiments were set to 3.45 and $62.5 \mathrm{~ms}$, corresponding to ${ }^{1} J_{\mathrm{C}, \mathrm{H}}=145 \mathrm{~Hz}$ and ${ }^{\mathrm{n}} J_{\mathrm{C}, \mathrm{H}}=$ $8 \mathrm{~Hz}$, respectively. The mixing time for the gs-NOESY was 1 second. Processing of the data was performed with the Mestre-C Software (Mestrelab Research). APCI-MS 
spectra were measured from a solution of the analyte in $\mathrm{MeCN} / \mathrm{H}_{2} \mathrm{O}$ with a Hewlett Packard MSD 1100 using an evaporator temperature of $400^{\circ} \mathrm{C}$, a drying gas temperature of $350^{\circ} \mathrm{C}$ at a flow of 6.0 liters/hour $\left(\mathrm{N}_{2}\right)$. In positive ionization mode, the capillary voltage amounted to $3.5 \mathrm{kV}$, the corona discharge current was $4.0 \mu \mathrm{A}$. In negative ionization mode, the capillary voltage amounted to $2.2 \mathrm{kV}$, the corona discharge current was $6.0 \mu \mathrm{A}$. ESI-HRMS data were measured from a solution of the analyte in $\mathrm{MeCN}$ with a Waters Q-TOF-Ultima 3 equipped with a LockSpray interface (tri- $n$-octylamine as external reference). IR and UV spectra were measured with a Bruker IFS48 FTIR spectrometer and a Perkin-Elmer Lambda-16 spectrophotometer, respectively. The optical rotations were measured with a Perkin-Elmer 241 polarimeter at $25^{\circ} \mathrm{C}$.

\section{Sterelactone A (1)}

The title compound was obtained as a slightly amber oil. $[\alpha]_{\mathrm{D}}^{25}=-19.4\left(c \quad 0.37, \mathrm{CHCl}_{3}\right)$. IR $v_{\max }(\mathrm{KBr}) \mathrm{cm}^{-1} 3437$ (br), 2931, 2865, 1735 (sh), 1667, 1455, 1402, 1368, 1159, 1096, 1053, 701. UV $\lambda_{\max }^{\mathrm{MeOH}} \mathrm{nm}(\log \varepsilon) 304$ (3.96). APCIMS (negative) $\mathrm{m} / z$ (\%) 345.1 (100) $[\mathrm{M}-\mathrm{H}]^{-}, 257.0$ (21), 213.0 (20). APCI-MS (positive) $\mathrm{m} / z$ (\%) 259.0 (100) $\left[\mathrm{M}-\mathrm{C}_{3} \mathrm{H}_{7} \mathrm{CO}_{2}\right]^{+}, \quad 241.0$ (54) $\left[\mathrm{M}-\mathrm{C}_{3} \mathrm{H}_{17} \mathrm{CO}_{2}-\mathrm{H}_{2} \mathrm{O}\right]^{+}$, 213.1 (16). ESI-HRMS calcd. for $\mathrm{C}_{19} \mathrm{H}_{22} \mathrm{O}_{6} \mathrm{Na}[\mathrm{M}+\mathrm{Na}]^{+}$ 369.1314 , found 369.1314 .

\section{Sterelactone B (2)}

The title compound was obtained as a yellowish oil. $[\alpha]_{\mathrm{D}}^{25}=-20.5\left(c 0.48, \mathrm{CHCl}_{3}\right)$. IR $v_{\max }(\mathrm{KBr}) \mathrm{cm}^{-1} 3432$ (br), 2961, 2933, 2872, 1774, 1739, 1667, 1467, 1403, 1366, 1165, 1095, 1052, 947, 883, 803, 763, 735. UV $\lambda_{\max }^{\mathrm{MeOH}} \mathrm{nm}(\log \varepsilon) 304$ (3.93). Nontrivial NOESY contacts: $1-\mathrm{H} \sim 15-\mathrm{H}_{3}, 5-\mathrm{H}_{\mathrm{b}} ; 5-\mathrm{H}_{\mathrm{b}} \sim 8-\mathrm{H}_{\mathrm{b}} ; 4-\mathrm{H} \sim 5-\mathrm{H}_{\mathrm{a}} ; \mathrm{CH}_{2} \mathrm{CO} \sim 14-$ $\mathrm{H}_{3}$. APCI-MS (negative) $\mathrm{m} / z(\%) 373.2(100)[\mathrm{M}-\mathrm{H}]^{-}$. APCI-MS (positive) $\mathrm{m} / \mathrm{z}(\%) 259.1$ (100) $\left[\mathrm{M}-\mathrm{C}_{5} \mathrm{H}_{11} \mathrm{CO}_{2}\right]^{+}$, 241.0 (57) $\left[\mathrm{M}-\mathrm{C}_{5} \mathrm{H}_{11} \mathrm{CO}_{2}-\mathrm{H}_{2} \mathrm{O}\right]^{+}, 213.1$ (16). ESI-HRMS calcd. for $\mathrm{C}_{21} \mathrm{H}_{26} \mathrm{O}_{6} \mathrm{Na}[\mathrm{M}+\mathrm{Na}]^{+}$397.1627, found 397.1616.

\section{Sterelactone C (3)}

The title compound was obtained as a slightly amber oil. $[\alpha]_{\mathrm{D}}^{25}=-23.8\left(c 0.45, \mathrm{CHCl}_{3}\right)$. IR $v_{\max }(\mathrm{KBr}) \mathrm{cm}^{-1} 3441$ (br), 2959, 2931, 2859, 1775, 1740, 1668, 1467, 1402, 1365, 1258, 1203, 1158, 1097, 1052, 947, 882, 805, 762, 736. UV $\lambda_{\max }^{\mathrm{MeOH}} \mathrm{nm}(\log \varepsilon) 304$ (3.89). Typical HMBCcontacts for the sterelactones (sorted by decreasing intensity): 12-H: C-6, C-3; 10-H: C-11, C-1, C-2, C-9, C-8; 1-H: C-9, C-15, Ester-CO, C-10, C-3, C-2, C-11, C-6; 8- ${ }_{\mathrm{a}}$ : C-7, C-9, C-5, C-10, C-13, C-2; 8- $\mathrm{H}_{\mathrm{b}}$ : C-9, C-7, C-6, C-5, $\mathrm{C}-2, \mathrm{C}-10 ; \alpha-\mathrm{CH}_{2}: \mathrm{CO}, \beta-\mathrm{C}, \gamma-\mathrm{C} ; \beta-\mathrm{CH}_{2}: \gamma-\mathrm{C}, \alpha$-C, Ester-
$\mathrm{CO} ; 5-\mathrm{H}_{\mathrm{a}}: \mathrm{C}-13, \mathrm{C}-4, \mathrm{C}-6, \mathrm{C}-7, \mathrm{C}-3, \mathrm{C}-8 ; 15-\mathrm{H}_{3}: \mathrm{C}-1, \mathrm{C}-11$ C-14, C-10; 14- $\mathrm{H}_{3}$ : C-15, C-11, C-1, C-10; 5- $\mathrm{H}_{\mathrm{b}}$ : C-8, C13, C-3, C-7, C-4, C-6. APCI-MS (negative) $\mathrm{m} / \mathrm{z}$ (\%) 401.2 (100) $[\mathrm{M}-\mathrm{H}]^{-}$. APCI-MS (positive) $m / z(\%) 403.2(7)$ $[\mathrm{M}+\mathrm{H}]^{+}, 259.0(100) \quad\left[\mathrm{M}-\mathrm{C}_{7} \mathrm{H}_{15} \mathrm{CO}_{2}\right]^{+}, \quad 241.1 \quad$ (57) $\left[\mathrm{M}-\mathrm{C}_{7} \mathrm{H}_{15} \mathrm{CO}_{2}-\mathrm{H}_{2} \mathrm{O}\right]^{+}, 213.1$ (12). ESI-HRMS calcd. for $\mathrm{C}_{23} \mathrm{H}_{30} \mathrm{O}_{6} \mathrm{Na}[\mathrm{M}+\mathrm{Na}]^{+} 425.1940$, found 425.1942 .

\section{Sterelactone D (4)}

The title compound was obtained as a slightly amber oil. $[\alpha]_{\mathrm{D}}^{25}=-21.0\left(c 0.52, \mathrm{CHCl}_{3}\right)$. IR $v_{\max }(\mathrm{KBr}) \mathrm{cm}^{-1} 3435$ (br), 2967, 2936, 2875, 1771, 1739, 1667, 1609, 1463, 1403, 1384, 1367, 1254, 1173, 1095, 1053, 946, 882, 802, 762, 735. UV $\lambda_{\max }^{\mathrm{MeOH}} \mathrm{nm}(\log \varepsilon) 304$ (3.97). APCI-MS (negative) $m / z \quad(\%) \quad 429.2(100) \quad[\mathrm{M}-\mathrm{H}]^{-}$. APCI-MS (positive) $\mathrm{m} / z$ (\%) 431.2 (9) $[\mathrm{M}+\mathrm{H}]^{+}, 259.0$ (100) $\left[\mathrm{M}-\mathrm{C}_{9} \mathrm{H}_{19} \mathrm{CO}_{2}\right]^{+}, \quad 241.0$ (53) $\left[\mathrm{M}-\mathrm{C}_{9} \mathrm{H}_{19} \mathrm{CO}_{2}-\mathrm{H}_{2} \mathrm{O}\right]^{+}$, 213.1 (12). ESI-HRMS calcd. for $\mathrm{C}_{25} \mathrm{H}_{34} \mathrm{O}_{6} \mathrm{Na}[\mathrm{M}+\mathrm{Na}]^{+}$ 453.2253, found 453.2250 .

Acknowledgments We thank the Kompetenzzentrum der integrierten Naturstoff-Forschung at the University of Mainz. We are grateful to Prof. Dr. T. Anke, Kaiserslautern, for providing the mycelial culture of strain IBWF 01060. The expert technical assistance of K. Gries and A. Meffert is gratefully acknowledged.

\section{References}

1. Daniewski WM, Kocor M, Thoren S. Constituents of higher fungi. Part VIII. Isolactarorufin, a novel tetracyclic sesquiterpene lactone from Lactarius rufus. Heterocycles 5: 77-84 (1976)

2. Konitz A, Bogucka-Ledochowska M, Dauter Z, Hempel A, Borowski E. The structure of isolactarorufin. Tetrahedron Lett 38: 3401-3402 (1977)

3. Erkel G, Anke T, Velten R, Gimenez A, Steglich W. Hyphodontal, a new antifungal inhibitor of reverse transcriptases from Hyphodontia sp. (Corticiaceae, Basidiomycetes). Z Naturforsch C Biosciences 49: 561-570 (1994)

4. Quack W, Anke T, Oberwinkler F, Giannetti BM, Steglich W. Antibiotics from basidiomycetes. V. Merulidial, a new antibiotic from the basidiomycete Merulius tremellosus Fr. J Antibiot 31: 737-741 (1978)

5. Giannetti BM, Steffan B, Steglich W, Quack W, Anke T. Antibiotics from basidiomycetes. Part 23. Merulidial, an isolactarane derivative from Merulius tremellosus. Tetrahedron 42: 3579-3586 (1986)

6. Zapf S, Hossfeld M, Anke H, Velten R, Steglich W. Darlucins A and B, new isocyanide antibiotics from Sphaerellopsis filum (Darluca filum). J Antibiot 48: 36-41 (1995)

7. Schwarz M, Koepcke B, Weber RWS, Sterner O, Anke H. 3Hydroxypropionic acid as a nematicidal principle in endophytic fungi. Phytochemistry 65: 2239-2245 (2004) 